\title{
Sulfur Transformation in a Saline Sodic Soil of the Lajas Valley
}

\author{
Raúl Pérez Escolar and M. A. Lugo López ${ }^{1}$
}

\section{INTRODUCTION}

The use of sulfur as an amendment is classical in the reclamation of saline sodic and sodic soils. Its effectiveness is largely dependent on the rate at which it is transformed to sulfuric acid by the action of some soil microorganisms. Saline sodic soils, by general rule, have a relatively high content of free calcium carbonate which reacts with the sulfuric acid to form gypsum. The relative solubility of gypsum permits ample circulation of mobile calcium ions to displace harmful exchangeable sodium in the soil colloids. The sulfate anion can be absorbed by plants, but most of it is washed down by percolation. Its retention by soil colloids is very low, especially when dealing with clays of low isoelectric points. If adequate amounts of good-quality fresh waters are available for leaching and, if good drainage is provided, the sodium can be easily removed from saline sodic soil profiles.

At the Lajas Valley, in southwestern Puerto Rico, there are about 5,000 acres of saline sodic soils (2). ${ }^{2}$ Various tests are under-way to determine the feasibility of reclamation thru the leaching of exchangeable sodium by using sulfur. So far, the sulfur-treated plots seem to be improving after an original application of 4 tons of elementary sulfur to the acre. This amount is required to produce the gypsum to provide the necessary calcium to displace around 12 meq. of exchangeable sodium/100 g. of soil of the upper foot of a Fe clay soil at the Lajas Valley.

This paper reports on a laboratory study to determine the rate of sulfur transformation to the $\mathrm{SO}_{4}$ form in a saline sodic soil from the Lajas Valley The objective of this exploratory study was to determine the rapidity with which sulfur transformation occurred under the particular soil conditions that prevail at Lajas. This might be helpful in predicting the expected action of sulfur in the recalmation of these types of soils.

\section{MATERIALS AND METHODS}

Soil for this study was taken from the uppermost-8 inches from a field at Colonia Fraternidad in the municipality of Guánica. It was mapped as a Fe clay. Bulk samples were taken for characterization of the soil. Particle-

${ }^{1}$ Associate Soil Scientist and Soil Scientist, respectively, Agr. Exp. Sta., University of P.R., Mayagüez Campus, Río Piedras, P.R.

2 Italic numbers in parentheses refer to Literature Cited, p. 123. 
size distribution was determined by the modified method of Kilmer and Alexander (3). Cation exchange capacity was measured by the barium acetate method. Saturation percentage was determined by measuring the amount of distilled water necessary to saturate $100 \mathrm{~g}$. of air-dry soil. Electrical conductivity was measured in the saturation extract with a standard Solubridge. The $\mathrm{pH}$ was determined electrometrically by means of a xeromatic $\mathrm{pH}$-meter. Soluble calcium and magnesium were determined by the E.D.T.A. method, whereas sodium was determined by substracting the milliequivalents of $\mathrm{Ca}+\mathrm{Mg}$ per liter from the electrical conductivity multiplied by 10. Exchangeable sodium percentage was then determined by plotting the values of soluble $\mathrm{Na}$ and $\mathrm{Ca}+\mathrm{Mg}$ in a nomogram (1).

For the laboratory experiment the air-dry soil was passed through a 2-mm. sieve. Forty-eight tin cans were then filled with $200 \mathrm{~g}$. each of soil. The treatment differentials included $0,4,8$, and 12 tons of elementary powdered sulfur to the acre furrow slice. The sulfur was thoroughly mixed with the soil. The soil was then kept at about 80-percent field capacity during the incubation period. Since the treatments were replicated 12 times, 2 cans from each treatment were removed at the end of each month, and $\mathrm{SO}_{4}$ and $\mathrm{pH}$ determinations were made. The experimental period lasted 6 months. The $\mathrm{SO}_{4}$ determination was made by mixing $50 \mathrm{~g}$. of air-dry soil with 250 cc. of distilled water to which $2 \mathrm{ml}$. of concentrated $\mathrm{HCl}$ had been added. The mixture was constantly shaken for 2 hours after which time it was filtered. Fifty milliliters of filtrate were taken for complete $\mathrm{SO}_{4}$ precipitation with 10-percent barium chloride. After removal of chlorides the $\mathrm{BaSO}_{4}$ precipitate was ignited until constant weight was attained.

\section{SOIL CHARACTERIZATION}

The topmost 13 inches of $\mathrm{Fe}$ soil ${ }^{3}$ consist of a very dark-gray (5YR 3/1) firm hard clay with many dark reddish-brown mottlings (5YR 3/3). The structure is well developed. It is underlaid by a 13- to 24-inch dark reddish brown (5YR 3/2) layer of friable clay with moderately well developed structure. The 24- to 48-inch layer is a dark reddish-brown (5YR 3/4) friable clay with a few small pebbles embedded, and moderately welldeveloped structure. The underlying 48- to 72-inch layer is a dark reddishbrown (5YR 3/3) clay of moderately developed structure (2).

Some of the soil characteristics are shown in the following tabulation:

Particle size distribution

Sand, percent

16.8

A Vertisol according to the 7th soil classification scheme. Vertisols are mineral soils with at least 20 inches of depth and more than 30 percent of clay in all horizons. They have one or more of the following characteristics: Gilgai formation, slickensides, and wedge-shaped structural units at some depth between 10 to 40 inches.

- Nomenclature according to the standard Munsell Soil Color Chart. 


$\begin{array}{lr}\text { Silt, percent } & 20.6 \\ \text { Clay, percent } & 62.6 \\ \text { Saturation percentage } & 75.0 \\ \text { Cation exchange capacity, meq./100 g. soil } & 47.7 \\ \text { Electrical conductivity mmhos./cm. } & 12.7 \\ \text { Soluble Ca + Mg meq. per liter } & 14.9 \\ \text { Soluble } \mathrm{Na} \text { meq. per liter } & 112.1 \\ \text { pH } & 8.0 \\ \text { Exchangeable sodium, percent } & 38.0\end{array}$

The soil used in the experiment was, therefore, alkaline and high in clay, exchange capacity, soluble salts, and exchangeable sodium.

\section{SULFUR TRANSFORMATION}

The results of the sulfur-transformation study in a saline sodic soil are shown in figure 1. At the end of the first month-interval 11 percent of the sulfur from the cans where sulfur was applied at the rate of 4 tons to the acre had been transformed into sulfates. The figures for the 8- and 12-ton treatments were 9.2 and 10.5, respectively. At the end of 2 months about 19 percent of the sulfur had been transformed in the 4- and 12-ton treatments, while the corresponding figure for the 8-ton treatment was only 15.6. By the end of the third month the transformation rate was reduced in the 12-ton treatment, i.e., it was only 23.5, around a 4-percent additional increase. In the other two treatments the additional rate of increase was around 10 percent. By the end of the fourth month, sulfur transformation in the 4-ton treatment increased to 37.8 percent, while the corresponding values for the 8- and 12-ton treatments were only 31.2 and 26.3 , respectively. Then the rate of transformation almost leveled up, with but slight additional increases of 1 percent or less, irrespective of treatment. Final values showed that where sulfur was applied at the rate of 4 tons to the acre almost 40 percent of the sulfur was transformed to sulfate in the 6month interval. The corresponding values for the 8- and 12-ton treatments were of the order of 32 and 29 percent, respectively.

Even though weight-wise the higher rates of sulfur produced larger amounts of sulfates, there was a tendency for these rates to be lower in percentage with increasing amounts of sulfur. These results obey the Law of Chemical Equilibrium in the sense that, since the final products, namely, $\mathrm{CaSO}_{4}, \mathrm{MgSO}_{4}$ and $\mathrm{Na}_{2} \mathrm{SO}_{4}$, resulting from the $\mathrm{Ca}$ displacing action, were not constantly leached from the cans, the resulting accumulation tended to reduce the reaction velocity or else shift the equilibrium to the left side of the equation. It is very possible also that with the increasing amounts of $\mathrm{SO}_{4}$ formed the osmotic concentration could have induced water stress, thus reducing bacterial development and action.

Table 1 shows the $\mathrm{pH}$ changes induced by the transformation of the 
sulfur. Except for the check treatment (0 sulfur), in the other treatments a decrease in $\mathrm{pH}$ values with time and rate was observed. However, the values for the fifth- and sixth-month periods were about the same within a

40

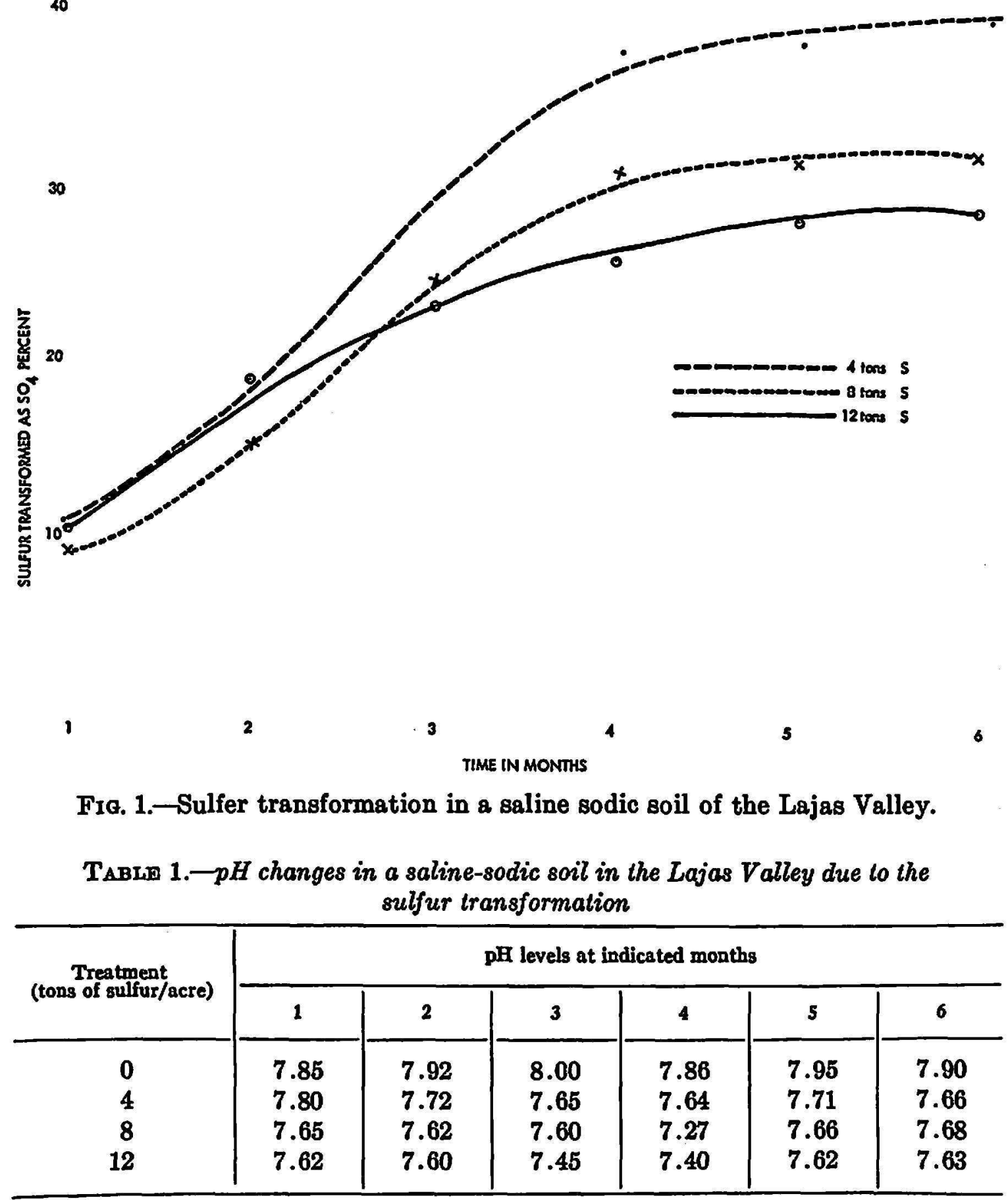

given treatment. Perhaps, neutralization occurred from the action of the sulfuric acid formed, the free carbonates present, and possibly some of the sodium, calcium, and magnesium adsorbed in the exchange complex. Other than errors in sampling techniques, there is no clear understanding of the 
fact that, while more sulfuric acid had been formed during the fifth month, the $\mathrm{pH}$ increased irrespective of treatment. In any case, this variation was 80 small, that it can perhaps be considered inconsequential.

These results further show that the transformation of sulfur occurs at a relatively rapid rate under laboratory conditions. Of course, as indicated previously in this paper, the soil used in this experiment was kept at a moisture content approaching field capacity, a condition which is generally difficult to maintain under field conditions. Yet, consideration must be given to the fact that salts produced during the course of this experiment were not removed, thus increasing water stress, a factor which is probably harmful for bacterial development and activity. From the conductivity values of the saturation extract of the soil before the sulfur application (12.7 mmhos./cm.) at least an osmotic concentration which equals a water tension of $4.2 \mathrm{~atm}$. prevailed, which must have increased with the production of sulfates. A point of additional interest is the high tolerance of the sulfur oxidizing organisms to exchangeable sodium levels as high as 38 percent, as prevailed under the conditions in which this study was conducted.

The study herein reported suggests possibilities for further research. One such possibility is the study of the rates of sulfoxidation when leaching the system. It might also be worthwhile to study the rapidity of sulfur transformation under different soil moisture levels. Finally, the sulfur oxidizing microorganisms should be isolated for their identification.

\section{SUMMARY}

Data are reported herein from a laboratory study to determine the rate of sulfur transformation on a saline sodic soil of the Lajas Valley, Puerto Rico. The soil was alkaline and high in clay, cation exchange capacity soluble salts, and exchangeable sodium. Treatment differentials included the use of sulfur at rates of 4,8 , and 12 tons to the acre furrow slice. Changes in the sulfate levels and $\mathrm{pH}$ were measured at monthly intervals from 1 to 6 months after applying the sulfur. At the first month interval sulfate levels were in the vicinity of 10 percent for all treatments. Sharper differences were measured at the end of the second month and thereafter until the fourth month. Final measurements showed rate of transformation of approximately 40,32 , and 29 for the 4-, 8- and 12-ton treatments, respectively. The $\mathrm{pH}$ decreased up to the fourth month, at which time it increased despite the sulfuric acid formed as shown by the sulfur transformed. This is perhaps casual. Sampling techniques could possibly account for this fact. The decrease in percent of sulfur transformed with increase in rate of sulfur applied can possibly be explained on the basis of the Law of Chemical Equilibrium, since the product formed, gypsum, was not removed to en- 
hance the velocity of the reaction to the right side of the equation. The relatively high tolerance of sulfur transformation organisms to high levels of free salts and exchangeable sodium is an important fact.

\section{RESUMEN}

En este trabajo se presenta la información obtenida de un estudio de laboratorio llevado a cabo para determinar la intensidad de la transformación de azufre elemental en un suelo salino sódico del Valle de Lajas en Puerto Rico. El suelo era alcalino y tenía un contenido alto de arcilla, sales libres y sodio intercambiable, como también una alta capacidad de intercambio iónico. Los tratamientos aplicados en el experimento incluyeron el uso del azufre elemental, a razón de 4, 8 y 12 toneladas por acre. Se midieron mensualmente los niveles de sulfatos y el $\mathrm{pH}$ del suelo hasta 6 meses después de aplicar el azufre. Durante el primer mes se obtuvieron valores de alrededor de un 10 por ciento en los tres tratamientos. Desde el segundo hasta el cuarto mes, los cambios fueron más notables. Las medidas finales tuvieron valores de 40,32 y 29 por ciento para los tratamientos de 4, 8 y 12 toneladas de azufre, respectivamente. Los valores de $\mathrm{pH}$ fueron descendiendo hasta el cuarto mes. Durante el quinto mes subieron y luego se estabilizaron al sexto mes. Probablemente, esto fue casual, pero, podría atribuirse, quizás, a la técnica usada durante el muestreo del suelo. El descenso en el porcentaje de la transformación de azufre, a medida que aumentaban los niveles de azufre elemental, pueden explicarse tomando como base la Ley de Equilibrio Químico, ya que el producto formado, yeso, no fue removido, medida ésta tomada para estimular la velocidad de la reacción hacia el lado derecho de la ecuación. De lo anterior se destaca un hecho importante, es decir, la tolerancia que tienen los organismos que transforman el azufre, a un alto contenido de sales libres y sodio intercambiable.

\section{LITERATURE GITED}

1. Agriculture Handbook No. 60 USDA, Saline and Alkali Soils.

2. Bonnet, J. A., Brenes, E. J., Detailed salinity survey of Lajas Valley, Agr. Expt. Sta. Univ. P.R., Bull. 141, July, 1958.

3. Kilmer, V. J., and Alexander, J. T., Methods of making mechanical analyses of soils, Soil Sci. 68: 15-24, 1949. 